\author{
Małgorzata Ewa Drywień ${ }^{1}$, AgnieszKa Kuć ${ }^{2}$ \\ ${ }^{1}$ Katedra Żywienia Człowieka \\ Wydział Nauk o Żywieniu Człowieka i Konsumpcji \\ Szkoła Główna Gospodarstwa Wiejskiego w Warszawie \\ Nowoursynowska 159C, 02-787 Warszawa \\ ${ }^{2}$ Zakład Dietetyki i Oceny Żywności \\ Instytut Nauk o Zdrowiu \\ Uniwersytet Przyrodniczo-Humanistyczny w Siedlcach \\ Prusa 14, 08-110 Siedlce \\ E-mail: malgorzata_drywien@sggw.pl \\ agnieszkakuc26@wp.pl
}

\title{
SPECYFIKA ZACHOWAŃ ŻYWIENIOWYCH OSÓB STARSZYCH POCHODZACYCH ZE ŚRODOWISKA WIEJSKIEGO
}

\section{WPROWADZENIE}

Starzenie się społeczeństwa jest powszechne we wszystkich rejonach świata, szczególnie intensywnie zachodzi ono w Europie i Ameryce Północnej. Subpopulację ludzi starszych charakteryzują: feminizacja, singularyzacja, spadek dochodów i pogorszenie stanu zdrowia (BŁEDOWSKI 2012). Populacja osób starszych mieszkających na wsi to $\mathrm{w}$ wielu przypadkach ludzie ubodzy, rozproszeni, pozostający często poza systemem emerytalno-rentowym i pomocy społecznej w zakresie zaspokojenia swoich potrzeb materialnych, nie objęci żadna dodatkowa pomoca (LESZCZYŃSKA-REJCHERT 2010). Środowisko seniorów wyróżnia wiele problemów takich jak: stan zdrowia, sytuacja ekonomiczna, warunki mieszkaniowe, dyskryminacja i marginalizacja społeczna, zmiany w obrębie rodziny, problemy adaptacyjne i emocjonalne, samotność oraz uzależnienia. W społeczeństwie osoba starsza jest postrzegana gorzej niż osoba młoda, a ma ona swoje potrzeby, które trzeba cały czas obserwować i starać się do nich dostosować po to, aby wraz ze wzrostem potrzeb wzrastała możliwość ich zaspokojenia (IWAŃSKI 2013).

Wiek życia człowieka wydłuża się niezależnie od środowiska społecznego, w 2013 r. długość życia kobiet na polskiej wsi wynosiła około 81 lat, a mężczyzn około 72 lata
(FRENKEL 2015). W tym kontekście poprawa jakości życia i stanu zdrowia jest elementem niezwykle istotnym, tym bardziej, że w ramach przyjętej przez Polskę Międzynarodowej Strategii Działania w Kwestii Starzenia się Społeczeństw (tzw. Plan Madrycki) sformułowane zostały najważniejsze obszary postępowania w stosunku do ludzi starszych, a w tym dbałość o dobry stan zdrowia i dobre samopoczucie (BŁEDOWSKI 2012). Dobry stan zdrowia i brak konieczności korzystania $z$ opieki zdrowotnej może $z$ jednej strony poprawiać samoocenę ludzi starszych, a $z$ drugiej, zmniejszać koszty leczenia w skali kraju. Prawidłowe zachowania żywieniowe maja kluczowe znaczenie w utrzymaniu zdrowia, tym samym decyduja o długości i jakości życia człowieka. Monitorowanie żywienia stanowi podstawę oceny ryzyka wystapienia niedoborów lub nadmiarów pokarmowych $u$ osób w starszym wieku oraz wynikajacych stąd skutków zdrowotnych. Bardzo ważne jest podejmowanie kroków w kierunku zmiany stylu życia, a zwłaszcza poprawy zwyczajów żywieniowych (RIVLIN 2007), ale poprzedzone musi być dokładnym rozpoznaniem środowiska wiejskiego.

Zdrowie dla osób starszych okazuje się być ważniejsze niż bezpieczeństwo dochodów, a jednak nie podejmuja oni działań w celu jego poprawy. Zwłaszcza osoby starsze mieszkające na wsi są na ogół bierne rucho- 
wo, a skłonność do podejmowania aktywności fizycznej maleje wraz $z$ wiekiem, przy tym posiłki spożywane sa nieregularnie, a zalecenia dotyczące spożywania 4-5 posiłków dziennie nie sa realizowane (IWAŃSKI 2013).

Sposób żywienia, stosunek do jedzenia, nawyki żywieniowe oraz preferencje w tym zakresie stanowia element stylu życia. Niewłaściwe odżywianie jest bezpośrednia przyczyna bądź czynnikiem ryzyka wielu schorzeń takich jak: otyłość, cukrzyca, niedokrwistość $z$ niedoboru, osteoporoza, nowotwory i choroby układu krażenia. Powstawanie tych schorzeń może być spowodowane nadmiarem energii pobieranej $z$ pożywieniem, jak i niedoborem żywieniowym oraz niewłaściwa jakością spożywanej żywności. Sposób żywienia jest czynnikiem różnicującym różne grupy społeczne, a wybory kulinarne są jedną ze wskazówek mówiących o przynależności do określonych kręgów społecznych (GÓRECKA i współaut. 2009).

Osoby starsze mieszkajace na wsi wybierając żywność bardzo często zwracaja uwage na to, aby była wystarczajaca do potrzeb zwiazanych $\mathrm{z}$ pracami $\mathrm{w}$ gospodarstwie, czyli aby była kaloryczna, obfita, ale zarazem niedroga. Często też nie zdają sobie sprawy $z$ tego, jakie sa konsekwencje określonej diety dla zdrowia i jakości życia. Nie eliminuja $z$ niej produktów i potraw uznanych za nieodpowiednie $\mathrm{w}$ racjonalnym żywieniu: tłustych i słodkich. Bardzo rzadko w diecie osób starszych można zauważyć sery, jogurty, świeże owoce, jarzyny i inne potrawy o charakterze prozdrowotnym, ponadto jest ona zazwyczaj monotonna (SzCZERBIŃSKA i współaut. 2011).

Sposób odżywiania, specyficzne potrawy, ich składniki i przyprawy podlegaja zróżnicowaniu regionalnemu. Mówiąc o kuchni wiejskiej wiadomo, że będzie się ona na ogół różnić zestawami jarzyn i ich rodzajem, sposobem przyrządzania mięs, używanymi do tego tłuszczami, ilością makaronów czy ziemniaków i lekkich bądź zawiesistych zup i sosów. Wszystkie te cechy przesązaja o tym, że tradycyjna kuchnię polska stosowana przez osoby mieszkajace na wsi uznać można za nieracjonalną. Jadłospisy wprawdzie uległy $z$ czasem uproszczeniu, a ilość spożywanych pokarmów zmniejszeniu, jednak nadal charakteryzuje się ona nadmierna wartościa energetyczna, jest zbyt bogata $\mathrm{w}$ tłuszcze zwierzęce, a uboga w błonnik, wapń i żelazo. Preferencje żywieniowe determinowane sa przez wiek, płeć, a następnie stan cywilny. Różnice żywieniowe moga być najbardziej widoczne pomiędzy kobietami i mężczyznami w koncepcjach żywieniowych oraz postrzeganiu własnego ciała. U osób starszych można zauważyć niewielką goto- wość do wprowadzania do jadłospisu nowych produktów. Ponadto, osoby starsze o gorszym stanie zdrowia maja tendencję do unikania potraw niskokalorycznych i lżej strawnych. Kobiety, które na ogół bardziej zwracaja uwage na to, co jedza, nie przenoszą wzorów zdrowego odżywiania na swoich mężów. Bardzo duże znaczenie ma pozycja społeczna, czyli dochód i wykształcenie, różnicujace bardziej wszechstronne preferencje i nawyki żywieniowe (SzCZERBIŃSKA i wspó1aut. 2011).

Zmniejszenie aktywności fizycznej, siły mięśni i wydolności narząów wewnętrznych to objawy ściśle zwiazane ze starzeniem się organizmu. Wynikiem tego jest zmniejszenie intensywności przemiany materii w porównaniu $z$ ludźmi młodszymi. Następuje pogorszenie przewodzenia impulsów nerwowych, czynność nerek zostaje upośledzona, a przesączanie kłębkowe zmniejsza się o ponad połowę, w porównaniu $z$ osobami młodszymi, zmniejszona zostaje także pojemność płuc. Zawartość składników mineralnych organizmu zmniejsza się, co powoduje demineralizację układu kostnego. W efekcie dochodzi do spowolnienia przemian metabolicznych $\mathrm{w}$ organizmie, a co za tym idzie, zmienia się zapotrzebowanie na energie i składniki odżywcze (LESZCZYŃSKA i współaut. 2008).

Układ pokarmowy osób starszych jest jednym $z$ tych, w którym zachodza najpoważniejsze zmiany. Zmniejsza się wyczuwalność smaku i zapachu, co powoduje utratę apetytu. Osoby mieszkajace na wsi bardzo często borykają się $z$ chorobami zębów i jamy ustnej, w tym częste są braki uzębienia, co skutkuje problemami z żuciem i rozdrabnianiem pokarmów (MIRCZAK 2014). Prowadzi to do ograniczenia spożywania niektórych trudno rozdrabnianych produktów, np. surowych warzyw i owoców, a także do problemów $z$ trawieniem. Zmiany dotycza też gruczołów ślinowych, gdyż osoby starsze wydzielają mniej śliny. Bardzo częstym objawem jest też ograniczenie czynności motorycznej przewodu pokarmowego i spowolnienie ruchów perystaltycznych, co skutkuje zaleganiem treści żoładkowej i jelitowej oraz zaparciami. Dochodzi także do zmian w wątrobie i układzie żółciowym oraz w trzustce, skutkiem czego jest zmniejszone wydzielanie żółci i insuliny. Bardzo częste są przypadki refluksu żołądkowo-przełykowego, który wpływa na łaknienie i jest odpowiedzialny za ograniczenie podaży niektórych składników odżywczych. Upośledzone zostają przemiany białek wynikajace $z$ procesów oksydacyjnych (ATHANASOPOULOU i współaut. 2018) oraz biotransformacja przyjmowanych leków, co spowodowane jest zwiazana $z$ wiekiem utrata części masy wątroby. Ograniczona zostaje 
aktywność enzymów trzustkowych, co pogarsza tolerancję posiłków. Zjawiskami mogącymi wpływać na zaburzenie prawidłowych nawyków żywieniowych sa samotność, depresja i zaburzenia funkcji układu nerwowego (JABEOŃSKI i KAŹMIERCZAK 2005). Osoby starsze zamieszkałe na terenach wiejskich sa bardziej narażone na wystapienie zespołu metabolicznego, do którego zalicza się otyłość brzuszna, dyslipidemię, cukrzyce oraz nadciśnienie tętnicze, chociaż zbyt duża i szybka redukcja masy ciała jest o wiele groźniejsza niż jej przyrost. Niezwykle ważna w tej grupie osób jest opieka medyczna i właściwa interwencja farmakologiczna w przypadkach leczenia cukrzycy, nadciśnienia, dyslipidemi, co skutecznie obniża liczbę zgonów $z$ przyczyn sercowo-naczyniowych. Jednak należy uwzględnić też możliwość zastosowania najtańszych metod profilaktyki zdrowotnej o potwierdzonej skuteczności, czyli rozwijanie wiedzy żywieniowej osób starszych i zachęcanie ich do prowadzenia zdrowego stylu życia poprzez właściwa dietę oraz zwiększona aktywność fizyczna, a także zachęcenie do kontrolowania parametrów metabolicznych i antropometrycznych (WYSOKIŃSKI 2014).

Jak dotąd w Polsce brak jest kompleksowego rozpoznania problemu sposobu żywienia i stanu odżywienia seniorów urodzonych i mieszkajacych na wsi, jako elementu istotnego $\mathrm{w}$ ochronie ich zdrowia, w opiece nad nimi oraz w szeroko pojętej polityce wyżywienia.

\section{WYBRANE ZACHOWANIA ŻYWIENIOWE}

W ostatnich latach wzrosło zainteresowanie stylem życia, w tym żywieniem osób starszych, jednak nadal niedostateczna jest wiedza o specyfice żywienia tej grupy populacyjnej zamieszkującej wieś.

W 2016 r. przeprowadzono pilotażowe badania własne w grupie 58 osób (35 kobiet i 23 mężczyzn) w wieku 65 lat i więcej, urodzonych i zamieszkujących przez całe życie wsie ze wschodnich obszarów województwa mazowieckiego. Osoby te wybrano spośród stu osób zrekrutowanych do badań. Ograniczona liczebność wynika ze sposobu doboru próby, wyrażenia zgody na udział w badaniach oraz możliwości komunikacji $Z$ respondentami wynikającej $z$ różnej precyzji $\mathrm{w}$ udzielaniu odpowiedzi. $Z$ respondentami przeprowadzono badanie ankietowe $z$ wykorzystaniem kwestionariusza, który składał się $z$ części ogólnej zawierającej metryczkę dotyczaca podstawowych danych socjo-demograficzych, takich jak: wykształcenie, wielkość gospodarstwa domowego, zasoby materialne na zakup żywności, pytania o samoocenę stanu zdrowia, zwyczaje żywie- niowe, aktywność fizyczna. Do pozyskania informacji o spożytej żywności wykorzystano kwestionariusz częstotliwości spożycia, który obejmował podstawowe grupy produktów spożywczych kluczowych $z$ punktu widzenia racjonalnego żywienia: produkty zbożowe, mleko i przetwory mleczne, mięso i wędliny, ryby, nasiona roślin straczkowych, warzywa, owoce (Suliga 2010, GRONOWSKA-SENGER 2014). Zapytano też o niektóre zwyczaje żywieniowe, takie jak: używanie soli, cukru, spożycie potraw smażonych, przyjmowanie suplementów diety. Podczas rozmowy $z$ respondentami pozyskiwano też informacje dotyczace zainteresowania zdobywaniem wiedzy na temat żywienia i żywności. Analizę statystyczna uzyskanych wyników przeprowadzono $z$ wykorzystaniem programu statystycznego PS IMAGO 4.0 (IBM SPSS Statistics 24). Za pomoca testu korelacji Rho Spearmana oraz rozkładu $\mathrm{Chi}^{2}$ zbadano zależności i zwiazki między wybranymi czynnikami charakteryzującymi badaną grupe osób a spożyciem grup produktów i zachowaniami żywieniowymi. Wyniki uznawano za istotnie statystyczne przy poziomie istotności $p \leq 0,05$ i $\mathrm{p} \leq 0,001$.

Wśród badanych $28 \%$ stanowily osoby w wieku od 65 do 70 lat, natomiast $62 \%$ osoby w wieku powyżej 70 lat. Badani od urodzenia mieszkali na terenach wiejskich, mieli wykształcenie podstawowe lub zawodowe, a jedynie 15\% wykształcenie średnie. Najmniej osób mieszkało w gospodarstwach sześcioosobowych i liczniejszych, prawie $1 / 3$ w gospodarstwach 3-5 osobowych, natomiast większość respondentów w gospodarstwach dwuosobowych. Większość ankietowanych, zarówno kobiet jak i mężczyzn, oceniła swoja sytuacje finansowa jako zła, deklarując brak wystarczającej ilości pieniędzy na zakup potrzebnej żywności. Natomiast co trzecia kobieta i co piąty mężczyzna ocenili swoja sytuacje jako dobra (Tabela 1).

$\mathrm{Na}$ podstawie deklarowanych danych ustalono, że średnia masa ciała badanych kobiet wynosiła $70 \mathrm{~kg}$, a mężczyzn $95 \mathrm{~kg}$, natomiast średni wzrost kobiet wynosił 165 $\mathrm{cm}$, a mężczyzn $173 \mathrm{~cm}$. Wartości wskaźnika BMI pozwoliły na ustalenie, że u znacznej większości badanych kobiet i mężczyzn (odpowiednio $60 \%$ i $75 \%$ ) był on w zakresie prawidłowym, u 26\% i $17 \%$ wskazywał na niedożywienie, a u pozostałych na otyłość (OżGa i MAEGORZEWICZ 2013).

W zakresie zwyczajów żywieniowych stwierdzono tendencje do spożywania większej liczby posiłków w ciagu dnia u mężczyzn w porównaniu do kobiet. Spożywanie 5 posiłków dziennie zdeklarowało po 5 osób każdej płci, 4 posiłki - 13 kobiet i 9 mężczyzn, 3 posiłki - 14 kobiet i 7 mężczyzn, a 
Tabela 1. Charakterystyka badanej grupy (liczba osób badanych).

\begin{tabular}{ll}
\hline Cecha & $\mathrm{N}$ \\
\hline Płeć: & 35 \\
Kobiety & 23 \\
Mężczyźni & 16 \\
\hline Wiek & 42 \\
65-70 lat & \\
powyżej 70 r.ż. & 13 \\
\hline BMI & 38 \\
niedowaga & 7 \\
norma & \\
nadwaga & 50 \\
\hline Wykształcenie & 8 \\
podstawowe & \\
średnie & 35 \\
\hline Wielkość gospodarstwa domowego & 17 \\
1-2 osób & 6 \\
3-5 osób & \\
6 osób i więcej & \\
\hline Ilość pieniędzy na zakup żywności \\
wystarczająca \\
niewystarczająca & \\
\hline
\end{tabular}

2 i mniej - 3 kobiety i 2 mężczyzn. Ponad połowa kobiet i mężczyzn miała zwyczaj dosalania lub dosładzania potraw lub napojów. Wśród respondentów można było zauważyć spożywanie tych samych produktów i potraw każdego dnia, co świadczy o małym urozmaiceniu jadłospisów. Do stosowania suplementów witaminowych i mineralnych przyznało sie jedynie 9 kobiet i 4 mężczyzn.

Cześć kobiet i mężczyzn deklarowała występowanie chorób lub dolegliwości wpływających na sposób żywienia. Problemy te występowały nieco częściej u kobiet niż u mężczyzn. Tylko co 7. kobieta odbyła rozmowe $z$ lekarzem na temat odpowiedniego odżywiania, natomiast żadna $z$ osób ankietowanych nie zadeklarowała stosowania specjalistycznej diety ani nie wyraziła chęci zdobycia nowych informacji na temat żywności i żywienia. Znacząca większość badanych nie dysponowała odpowiednimi środkami finansowymi na zakup żywności. Najczęstszymi czynnikami decydujacymi o wyborze żywności przez badane osoby były względy smakowe, przyzwyczajenia, cena produktów, względy zdrowotne, latwość dostępu, reklama.
Analiza częstotliwości spożycia wybranych grup produktów wśród osób starszych mieszkających na wsi wykazała niezależnie od płci, że owoce, warzywa i produkty zbożowe jadane były raz dziennie i rzadziej (Tabela 2). Większość badanych spożywała mleko i przetwory mleczne oraz mięso i wędliny raz dziennie i częściej. W przypadku nasion roślin strączkowych i ryb wykazano ich bardzo rzadkie spożycie, natomiast badani chętnie jadali potrawy smażone.

Ponadto stwierdzono, że $74 \%$ badanych mężczyzn i $45 \%$ kobiet dosalało potrawy, a dosładzało tyle samo mężczyzn i $63 \%$ kobiet. Jedynie 3 osoby wypijały ponad 8 szklanek napojów dziennie, czyli zgodnie $z$ zaleceniami, pozostali deklarowali spożycie mniejszej ilości płynów, a 25 osób (15 kobiet i 10 mężczyzn) piło mniej niż 4 szklanki.

Opierając się na wynikach analizy korelacji Rho Spearmana wykazano, że wartości BMI dodatnio korelowały $z$ częstościa dodawania cukru do potraw $(\mathrm{r}=0,553$, $\mathrm{p}<0,001)$. Częstotliwość spożycia owoców i warzyw była dodatnio skorelowana ze spożywaniem produktów zbożowych (odpowiednio: $\mathrm{r}=0,555, \mathrm{p}<0,001$ i $\mathrm{r}=0,535, \mathrm{p}<0,001)$, mleka (odpowiednio: $\mathrm{r}=0,669, \mathrm{p}<0,001$ i $\mathrm{r}=0,583$, $\mathrm{p}<0,001)$, a także nasion roślin strączkowych (odpowiednio: $\mathrm{r}=0,289, \mathrm{p}<0,03$ i $\mathrm{r}=0,281$, $\mathrm{p}<0,03)$. Produkty zbożowe były częściej spożywane przez osoby często spożywajace mleko $(r=0,577, p<0,001)$, mięso $(r=0,376$, $\mathrm{p}<0,004)$ oraz ryby $(\mathrm{r}=0,270, \mathrm{p}<0,04)$. Dodawanie cukru i soli do potraw korelowało wzajemnie dodatnio $(\mathrm{r}=0,283, \mathrm{p}<0,03)$.

Analiza badań przeprowadzona wśród osób starszych mieszkających na wsi wykazała nieprawidłowości w zachowaniach żywieniowych badanych osób. Podstawowa przemiana materii zmniejsza się wraz $z$ wiekiem, a w konsekwencji zmniejsza się zapotrzebowanie na makroskładniki (JAROSZ i RYCHLIK 2008). Jednak zapotrzebowanie na niektóre mikroskładniki zwiększa się, tak więc dieta osób starszych powinna cechować się duża gęstościa odżywcza, czyli dostarczać zwiększoną ilość składników mineralnych i witamin na jednostkę energii. Osoby starsze powinny regularnie spożywać 4-5 posiłków dziennie (RoszKowsKI 2010), natomiast $w$ badaniach własnych zalecenia te spełniało $50 \%$ ankietowanych kobiet i $62 \%$ mężczyzn. W przeprowadzonym badaniu zauważono częste spożycie mięsa i wędlin, potraw smażonych, słodyczy oraz dodawanie cukru do produktów i napojów, co najbardziej było widoczne u mężczyzn. Co prawda częstość spożycia nie zawsze dodatnio koreluje $z$ ilościa, ale może być wskazówką do pogłębienia analiz, gdyż pobieranie tych produktów w zwiększonej ilości prowadzić może 
Tabela 2. Częstość spożywania wybranych grup produktów spożywczych w badanej populacji zależnie od płci.

\begin{tabular}{|c|c|c|c|c|c|c|}
\hline \multirow{2}{*}{ Wyróżnik } & \multicolumn{2}{|l|}{ Częstość* } & \multicolumn{4}{|c|}{ Częstość (\% z płci) } \\
\hline & $\mathrm{X} ; \mathrm{SD}$ & $\mathrm{M}$ & $1^{* *}$ & 2 & 3 & 4 \\
\hline \multicolumn{7}{|c|}{ Owoce $\quad(p=0,76)$} \\
\hline Kobiety & 2,$29 ; \quad 1,1$ & 2 & 31,4 & 25,7 & 25,7 & 17,1 \\
\hline Mężczyźni & 2,$39 ; \quad 1,0$ & 3 & 26,1 & 21,7 & 39,1 & 13,0 \\
\hline \multicolumn{7}{|c|}{ Warzywa $(p=0,74)$} \\
\hline Kobiety & 2,$60 ; 1,4$ & 3 & 22,9 & 22,9 & 25,7 & 28,6 \\
\hline Mężczyźni & 2,$61 ; 1,1$ & 3 & 21,7 & 17,4 & 39,1 & 21,7 \\
\hline \multicolumn{7}{|c|}{ Produkty zbożowe $(\mathrm{p}=0,83)$} \\
\hline Kobiety & 1,$97 ; 1,2$ & 2 & 48,6 & 22,9 & 11,4 & 17,1 \\
\hline Mężczyźni & 1,$87 ; 1,1$ & 1 & 52,2 & 26,1 & 4,3 & 17,4 \\
\hline \multicolumn{7}{|c|}{ Mleko i przetwory $(p=0,15)$} \\
\hline Kobiety & 2,$97 ; 0,9$ & 3 & 8,6 & 17,1 & 42,9 & 31,4 \\
\hline Mężczyźni & 3,$04 ; 1,2$ & 4 & 17,4 & 13,0 & 17,4 & 52,2 \\
\hline \multicolumn{7}{|c|}{ Mięso i przetwory $(p=0,05)$} \\
\hline Kobiety & $2,60^{\text {a: }} ; 1,1$ & 3 & 20,0 & 28,6 & 22,9 & 28,6 \\
\hline Mężczyźni & $3,22^{\mathrm{b}} ; \quad 0,7$ & 3 & 0,0 & 17,4 & 43,5 & 39,1 \\
\hline \multicolumn{7}{|c|}{ Ryby $(p=0,75)$} \\
\hline Kobiety & 1,$26 ; \quad 0,6$ & 1 & 80,0 & 14,3 & 5,7 & 0,0 \\
\hline Mężczyźni & 1,$30 ; \quad 0,6$ & 1 & 73,9 & 21,7 & 4,3 & 0,0 \\
\hline \multicolumn{7}{|c|}{ Nasiona strączkowych $(p=0,31)$} \\
\hline Kobiety & 1,$09 ; \quad 0,3$ & 1 & 91,4 & 8,6 & 0,0 & 0,0 \\
\hline Mężczyźni & 1,$17 ; \quad 0,4$ & 1 & 82,6 & 17,4 & 0,0 & 0,0 \\
\hline \multicolumn{7}{|c|}{ Produkty smażone $(\mathrm{p}<0,001)$} \\
\hline Kobiety & $1,23^{\mathrm{a}} ; 0,4$ & 1 & 77,1 & 22,9 & 0,0 & 0,0 \\
\hline Mężczyźni & $2,70^{\mathrm{b}} ; \quad 0,8$ & 2 & 0,0 & 52,2 & 26,1 & 21,7 \\
\hline
\end{tabular}

Częstość: wartość średnia i odchylenie standardowe; mediana na podstawie skali 4-punktowej, gdzie 1 - rzadziej niż raz w tygodniu; 2 - kilka razy w tygodniu; 3 - raz dziennie; 4 - kilka razy dziennie. ${ }^{a-b}$ Wartości średnie dla danej grupy produktów oznaczone różnymi literami różnią się istotnie statystycznie przy p<0,05 (ANOVA).

do nadmiernego spożycia energii, tłuszczów oraz cukrów prostych, a co za tym idzie zwiększa się ryzyko otyłości, chorób układu krążenia, cukrzycy czy niektórych nowotworów. Nie jest znany rodzaj tłuszczu stosowany do smażenia, ale biorac pod uwage częstość jadania tak przygotowanych potraw można przypuszczać, że ich wartość energetyczna była znaczna, bowiem dodatek 1 łyżki tłuszczu do smażenia zwiększa kaloryczność potrawy średnio o około $100 \mathrm{kcal}$ (KUNACHOWICZ i współaut. 2012). Może to też niekorzystnie zmieniać proporcje $\mathrm{w}$ dostarczaniu energii przez makroskładniki. Pomimo że wraz $z$ wiekiem zmniejsza się synteza laktazy, co może powodować nietolerancję cukru mlecznego i dokuczliwe dolegliwości (KALIBATIENE i współaut. 2006), to jednak w badanej populacji wszyscy spożywali mleko, co jest zjawiskiem bardzo korzystnym w tej grupie wiekowej, szczególnie w przypadku kobiet. Badania przeprowadzone przez WŁODARKA i współaut. (2012) wykazały niska podaż wapnia u kobiet po 65. roku życia, co wskazuje na zbyt małe spożycie produktów mlecznych, będących głównym źródłem tego składnika. Jednak te same badania potwierdziły, że częstość spożycia produktów mlecznych koreluje dodatnio $z$ podażą wapnia. W badaniu własnym ustalono, że większość badanych spożywała mleko i jego przetwory co najmniej raz dziennie. Można więc przypuszczać, że w populacji wiejskiej mleko jest podstawowym źródłem tego składnika. W badaniach stwierdzono niezbyt częste spożycie produktów, takich jak owoce i warzywa, rośliny strączkowe, ryby i produkty zbożowe. WHO (2000) zaleca spożywanie warzyw i owoców w ilości nie mniej niż $400 \mathrm{~g} / \mathrm{dzien}$, w praktyce powinny to być 2 porcje owoców i 3 porcje warzyw dziennie, które powinny być dodawane do każdego posiłku (WolnicKA i RYCHLIK 2008). Stosowanie się do tych zaleceń wśród badanej populacji można zauważyć u 14\% osób w przypadku owoców i $28 \%$ w przypadku warzyw. Nie sa to wyniki zadowalajace ponieważ sugeruja, że osoby starsze moga mieć niedobory witaminy C oraz niektórych składników mineralnych, np. potasu, ale też błonnika pokarmowego, który reguluje prace przewodu pokarmowego i zapobiega zaparciom. 
Rośliny straczkowe nie cieszyły się popularnością wśród badanych. Wynikać to może stąd, że sa produktami ciężkostrawnymi mogącymi powodować wzdęcia i odczucie dyskomfortu. Także zbyt długi czas przygotowania tych produktów i zbyt mała ilość znanych przepisów kulinarnych mogła mieć na to wpływ (GóRNICKA i współaut. 2011). Produkty zbożowe sa źródłem węglowodanów złożonych, które powinny pokrywać 50$60 \%$ dziennego zapotrzebowania na energię. Wśród osób ankietowanych częstotliwość ich spożycia nie była duża $\mathrm{i}$ potwierdza spadkową tendencję $\mathrm{w}$ konsumpcji produktów zbożowych $\mathrm{w}$ Polsce $\mathrm{w}$ ostatnich latach (WINEK 2015). Obserwacje te sa też zbieżne $z$ wynikami DZIEDZIC i współaut. (2015), że większa część badanych po 65. roku nie jada produktów zbożowych kilka razy dziennie, a o wiele rzadziej. JEŻEWSKA-ZYCHOWICZ i KRÓLAK (2015) wykazały, że co czwarta osoba po 55. roku życia jada jeden ulubiony rodzaj pieczywa, najczęściej pszenne lub mieszane, kupujac je raz w tygodniu. Można na tej podstawie stwierdzić, że osoby starsze mieszkajace na wsi wykazuja niewłaściwe zachowania żywieniowe $\mathrm{w}$ aspekcie produktów zbożowych, które powinny być dla nich znaczącym źródłem węglowodanów złożonych, a także witamin i składników mineralnych. Wśród badanej populacji zbyt mała była częstotliwość spożycia ryb, prawdopodobnie wynikajaca $z$ ugruntowanych tradycyjnych zwyczajów żywieniowych, a która jest niekorzystna $z$ punktu widzenia prawidłowej podaży wielonienasyconych kwasów tłuszczowych (n-3) i witaminy D w tej grupie wiekowej.

Wiek powyżej 65. roku życia jest czynnikiem ryzyka odwodnienia organizmu, które prowadzić może m.in. do zaburzeń gospodarki elektrolitowej, a w efekcie do zaburzenia rytmu serca, zmian przewodzenia, pracy nerek, ale też pogorszenia funkcji mózgu (JAROSZ i RYCHLIK 2005). Zapotrzebowanie na wodę u osób starszych wynosi 25-30 ml/ kg masy ciała, a aktualne zalecenia mówia, że nie powinno być niższe niż $2000 \mathrm{ml} /$ dzień dla kobiet i $2500 \mathrm{ml} /$ dzień dla mężczyzn (JoŚKO-OCHOJSKA i współaut. 2014). Aby zrealizować te wymagania osoby po 65 . roku życia powinny wypijać 8 szklanek płynów dziennie. U badanych osób starszych podaż płynów była niedostateczna, zwłaszcza $u$ tych $z$ najniższym wskaźnikiem BMI, co wymaga większej kontroli oraz podejmowania środków zaradczych. Niepokojące jest też stwierdzone u respondentów częste dosalanie i dosładzanie potraw, co jest efektem zmian fizjologicznych zmysłu smaku, ale też wynika ze zwyczajów, które sa w tej grupie populacyjnej dosyć konserwatywne i wynika- ja $z$ tradycji. Natomiast zjawisko to wymaga potwierdzenia $\mathrm{w}$ badaniach ilościowych $\mathrm{w}$ celu sprawdzenia, czy spożycie soli kuchennej przekracza 5g/dzień (WHO/FAO 2003).

Brak wystarczajacej ilości pieniędzy na zakup odpowiedniej żywności, deklarowany przez większość ankietowanych, może pogłębiać powyższe nieprawidłowości żywieniowe. Efektem było stosowanie tych samych produktów każdego dnia, a odsetek osób starajacych się urozmaicić swój jadłospis był niski. Osoby starsze narażone sa na występowanie nie tylko chorób dietozależnych, ale też niedożywienia (MIRCZAK 2014), a więc dietoprofilaktyka $\mathrm{w}$ tym przypadku jest bardzo istotna, co powinno być promowane zwłaszcza przez lekarzy pierwszego kontaktu. Wyniki własnych badań pilotażowych wykazały, że żadna $\mathrm{z}$ osób ankietowanych nie rozmawiała $z$ lekarzem na temat żywienia. Znaczna część ankietowanych nie była też zainteresowana zdobywaniem wiedzy na temat żywności i żywienia, a względy zdrowotne decydowały o wyborze żywności tylko u $20 \%$ badanych.

Wyniki ostatnio prowadzonych badań wykazały, że osoby starsze mieszkajace na wsi sa populacja o słabo rozpoznanych zwyczajach i nawykach żywieniowych, tym samym mało jest informacji na temat ilościowego aspektu ich sposobu żywienia. Konieczne zatem wydaje się podejmowanie wszelkich działań edukacyjnych skierowanych do osób starszych mieszkających na wsi oraz ich opiekunów, ale także zwrócenie uwagi lekarzy na ten problem, tym bardziej, że dobra wiedza zwiazana $z$ odżywianiem i pozytywne postawy wobec żywienia moga silnie i korzystnie wpływać na stan zdrowia i jakość życia osób starszych (JERUSzKA-BIELAK i współaut. 2018). Istnieje potrzeba prowadzenia badań nad interakcjami pomiędzy zachowaniami żywieniowymi a innymi zachowaniami związanymi ze stylem życia w celu zapobiegania zaburzeniom wieloetiologicznym w starszym wieku (MARSEGLIA i współaut. 2018).

\section{PODSUMOWANIE}

W żywieniu badanej grupy osób starszych stwierdzono nieprawidłowości pod względem jakościowym oraz $\mathrm{w}$ zachowaniach żywieniowych, mogace mieć negatywne konsekwencje w nieodpowiedniej podaży wielu składników odżywczych. Stanowi to ryzyko niedożywienia, nadwagi i otyłości, zaburzeń lipidowych, cukrzycy typu 2, nadciśnienia tętniczego, choroby niedokrwiennej serca i innych chorób przewlekłych oraz funkcji poznawczych, co $\mathrm{w}$ efekcie może prowadzić do pogorszenia jakości ich życia. W propagowa- 
niu zasad racjonalnego żywienia wśród osób starszych należy zwrócić szczególną uwage na regularność spożycia posiłków, nie stosowanie dosalania i dosładzania potraw oraz unikania spożywania potraw smażonych, zwłaszcza wśród mężczyzn. Dla pozyskania kompleksowych informacji celowe wydaje się przeprowadzenie badań sposobu żywienia rdzennych mieszkańców wsi na szeroka skalę $z$ wykorzystaniem narzędzi badawczych pozwalajacych na uzyskanie danych ilościowych.

\section{Streszczenie}

W ostatnich latach wzrosło zainteresowanie stylem życia osób starszych, w tym żywieniem, jednak nadal niedostateczna jest wiedza o specyfice żywienia tej grupy populacyjnej zamieszkujaccej wieś. W przeprowadzonym ankietowym badaniu własnym (58 osób, w tym 35 kobiet i 23 mężczyzn) zauważono częste spożycie mięsa i wędlin, potraw smażonych, słodyczy oraz częste dodawanie cukru do produktów i napojów, co najbardziej było widoczne u mężczyzn. Znacząca większość badanych nie dysponowała odpowiednimi środkami finansowymi na zakup żywności. Najczęstszymi czynnikami decydujacymi o wyborze żywności przez badane osoby były względy smakowe, przyzwyczajenia, cena produktów, względy zdrowotne, łatwość dostępu, reklama. W badanej grupie osób starszych stwierdzono wiele nieprawidłowych zachowań żywieniowych, stanowiących ryzyko niedożywienia lub zespołu metabolicznego, co w efekcie może prowadzić do pogorszenia jakości ich życia. Konieczne zatem wydaje się podejmowanie wszelkich działań edukacyjnych skierowanych do osób starszych mieszkajacych na wsi oraz ich opiekunów, ale także zwrócenie uwagi lekarzy na ten problem.

\section{LITERATURA}

Athanasopoulou S., CHONDROGiAnNi N., SANTORO A., Asimaki K., Delitsikou V., Voutetakis K., FabBri C., Pietruszka B., Kaluza J., FranceSCHI C., GONOS E.S., 2018. Beneficial effects of elderly tailored mediterranean on the proteasomal proteolysis. Front. Physiol. 9, 457.

BŁĘDOWSKI P., 2012. Raport na temat sytuacji osób starszych $w$ Polsce. Instytut Pracy i Spraw Socjalnych, Warszawa, 30, 181-188.

DZIEDZIC B., SiENKIEWICZ Z., IMIELA J., 2015. Analiza wybranych zachowań zdrowotnych osób po 65 roku życia ze stwierdzona choroba niedokrwienna serca. Gerontol. Pol. 3, 47-56.

FRENKEL I., 2015. Przemiany demograficzne $i$ aktywność ekonomiczna ludności wiejskiej $w$ la tach 2010-2013. Wieś i Rolnictwo 167, 33-62.

GóRECKA D, CZARNOCIŃSKA J, IDZIKOWSKI M, KOWALEC J., 2009. Postawy osób dorosłych wobec żywności funkcjonalnej $w$ zależności od wieku $i$ ptci. Zywn. Nauka. Technol. Jakość 4, 320-326.

GÓRNICKA M., PIERZYNOWSKA J., WiŚNIEWSKA M., FRĄCKIEWICZ J., 2011. Analiza spożycia suchych nasion straczkowych $w$ latach 1999$2008 w$ Polsce. Bromat. Chem. Toksykol. 44, 1034-1038.

GRONOWSKA-SENGER A., 2014. Przewodnik metodyczny badań sposobu żywienia. Warszawa, Komitet Nauki o Żywieniu Człowieka Polskiej Akademii Nauk Warszawa, 2-13. http://
www.knozc.pan.pl/images/Przewodnik_metodyczny_calosc.pdf.

IWAŃSKI R. 2013. Zrównoważony rozwój obszarów wiejskich a sytuacja osób starszych na wsi. Folia Pomer. Univ. Technol. Stetin. 70, 81-90.

JABŁOŃSKI E., KAŽMIERCZAK U., 2005. Odżywianie się osób $w$ podeszłym wieku. Gerontol. Pol. $13,48-54$.

JAROSZ M., RYCHLIK E., 2005. Składniki mineralne, witaminy woda - przyczyny niedoboru u osób w wieku podeszłym. Żyw. Człow. Metab. 32, 348-357.

JAROSZ M., RYCHLIK E., 2008. Przyczyny niedoboru makro i mikroskładników u osób $w$ wieku starszym. [W:] Żywienie osób w starszym wie$k u$. JAROSZ M. (red.). PZWL, Warszawa, 4051.

Jeruszka-BielaK M., Kollajtis-Dolowy A., SANTORO A., Ostan R., BERENDSEN A. A. M., JenNings A., Meunier N., Marseglia A., CAUMON E., Gillings R., DE GROOT L. C. P. G. M., Franceschi C., Hieke S., Pietruszka B., 2018. Are nutrition-related knowledge and attitudes reflected in lifestyle and health among elderly people? A study across five European countries. Front. Physiol. 9, 994.

JEŻEWSKA-ZYCHOWICZ M., KRÓLAK M., 2015. Zachowania konsumenckie na rynku pieczywa $i$ ich wybrane uwarunkowania. Handel Wewnętrzny $2,185-196$.

JOŚKO-OCHOJSKA J., SPANDEL L., BRUS R., 2014. Odwodnienie osób $w$ podeszłym wieku jako problem zdrowia publicznego. Hygeia Public Health 49, 712-717.

Kalibatiene D., VARvUolyte S., Alekna V., 2006. Investigation of hypolactasia in the elderly. Gerontologija 7, 136-142.

KunACHOWICZ H., NADOLNA I., IwaNOW K., 2012. Wartość odżywcza wybranych produktów spożywczych $i$ typowych potraw. PZWL, Warszawa.

LESZCZYŃSKA T., SIKORA E., BIEŻANOWSKA-KOPEĆ R., PYSZ K., NOWACKA E., 2008. Ocena prawidłowości bilansowania składu racji pokarmowych osób starszych zamieszkujacych w wybranych domach pomocy społecznej oraz $w$ zakładzie opiekuńczo-leczniczym. Żywn. Nauka Technol. Jakość 2, 140-154.

LESZCZYŃSKA-REJCHERT A., 2010. Człowiek starszy $i$ jego wspomaganie - $w$ strone pedagogiki starości. UWM, Olsztyn.

Marseglia A., XU W., Fratiglioni L., Fabbri C., Berendsen A. A. M., BialeckA-DEBeK A., JenNings A., Gillings R., Meunier N., CAumon E., FAIRWEATHER-TAIT S., PIETRUSZKA B., DE GROOT L. C. P. G. M., SANTORO A., FRANCESCHI C., 2018. Effect of the NU-AGE diet on cognitive functioning in older adults: a randomized controlled trial. Front. Physiol. 9, 349.

MiRCZAK A., 2014. Czynniki determinujace ryzyko niedożywienia osób starszych ze środowiska wiejskiego, Med. Środ. 17, 68-75.

OżGA E., MAEGORZEWICZ S., 2013. Ocena stanu odżywienia osób starszych, Geriatria 7, 1-6.

RIVLIN R. S., 2007. Keeping the young - elderly health: is it too late to improve our health trough nutrition ? Am. J. Clin. Nutr. 86, 1572-1576.

RosZKOWSKI W., 2010. Żywienie osób starszych. [W:] Żywienie człowieka zdrowego i chorego. GRZYMISEAWSKI M., GAWECKI J. (red.). Wydawnictwo Naukowe PWN, Warszawa, 80-86.

SUligA E., 2010. Zachowania zdrowotne zwiazane $z$ żywieniem osób dorosłych $i$ starszych. Hygeia Public Health 45, 44-48. 
SzCZERBińsKa K., MALINOWSKA-CIEŚlik M., PióRECKA B., GIUSTINI M., 2011. Jak skutecznie zmieniać zachowania zdrowotne pacjentów $w$ starszym wieku. Przegl. Lek. 68, 1183-1189.

WHO (World Health Organization), 2000. Obesity: preventing and managing the global epidemic. WHO Technical Report Series http:// webcache.googleusercontent.com/search?q=cache:faiI09-VX5wJ:www.who.int/nutrition/ publications/obesity/WHO_TRS_894/en/+\&c$\mathrm{d}=1 \& \mathrm{khl}=\mathrm{pl} \& \mathrm{ct}=\mathrm{clnk} \& \mathrm{gl}=\mathrm{pl}$.

WHo/FAO, 2003. Diet, nutrition and the prevention of chronic diseases. WHO Technical Report Series 916, http://apps.who.int/iris/bitstream/10665/42665/1/WHO TRS 916.

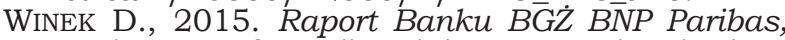
Zmiany preferencji Polaków $w$ zakresie kon- sumpcji żywności. BGŻ BNP Paribas, Warszawa, 21-23.

WŁodAREK D., SobocińsKa A., GŁABSKA D., 2012. Podaż wapnia $z$ produktów mlecznych $w$ diecie kobiet po 60 roku życia. Bromat. Chem. Toksykol. 45, 833-838.

WOLNICKA K., RYCHLIK E., 2008. Praktyczne wskazówki do realizacji zaleceń żywieniowych dla osób $w$ wieku starszym. [W:] Żywienie osób $w$ starszym wieku. JAROSZ M. (red.). PZWL, Warszawa, 70-88.

WYSOKIŃSKI A., 2014. Odmienności metaboliczne wieku podeszłego w kontekście leczenia przeciwpsychotycznego. Psychogeriatria Polska 11, 41-52.

KOSMOS Vol. 68, 2, 303-310, 2019

\section{Matgorzata Ewa Drywieñ ${ }^{1}$, AgnieszKa KuĆ²}

${ }^{1}$ Department of Human Nutrition, Faculty of Human Nutrition and Consumer Sciences, Warsaw University of Life Sciences, 159C Nowoursynowska Str., 02-787 Warszawa, ${ }^{2}$ Division of Dietetics and Food Assessment, Department of Health Sciences, Siedlce University of Natural Sciences and Humanitie, 14 Prusa Str., 08-110 Siedlce, E-mail: malgorzata_drywien@sggw.pl

\section{THE SPECIFICITY OF EATING BEHAVIOR OF OLDER PEOPLE FROM THE RURAL AREA}

\section{Summary}

In recent years there is increasing interest in the lifestyle of older people, including nutrition. However, the knowledge of the specific nutritional habits of this population group living in the country is still insufficient. In our own study, frequent consumption of meat and cold meats, fried dishes, sweets and frequent addition of sugar to products and beverages was noticed, which was most visible in men. The vast majority of respondents did not have adequate finances to buy food. The most common factors determining the choice of food were taste, habits, product prices, health considerations, ease of access, advertising. In the inquired pool group of elderly people (58 respondents, including 35 women and 23 men), many abnormal nutritional behaviors were found, constituting the risk of malnutrition or metabolic syndrome, which in turn may lead to deterioration of their quality of life. Therefore, it seems necessary to undertake all educational activities directed to elderly people living in the countryside and their careers, but also to draw attention of the physicians to this problem.

Keywords: elderly, nutrition, rural area 